\title{
Production of Monoclonal Antibodies against Recombinant HBcAg
}

\author{
Yoshiyuki Ueno, Koju Kobayashi, Hiroshi Suzuki, \\ Takeshi Yamamoto and Takayoshi Toyota
}

The Third Department of Internal Medicine, Tohoku University School of Medicine, Sendai 980

Ueno, Y., Kobayashi, K., Suzuzki, H., Yamamoto, T. and Toyota, T. Production of Monoclonal Antibodies against Recombinant HBcAg. Tohoku J. Exp. Med., 1990, 161 (3), 253-255 — Three monoclonal antibodies against recombinant $\mathrm{HBcAg}$ were obtained from hybridomas fused between mouse myeloma line $\mathrm{NS1}$ and splenocytes of immunized Balb/C mice. They specifically bound to recombinant HBcAg. Subtypes of these monoclonal antibodies were IgM and $\operatorname{IgA}$. recombinant $\mathrm{HBcAg}$; monoclonal antibodies; anti-HBc

Monoclonal antibodies have several advantages to polyclonal antibodies, such as their purity and specific binding to an epitope. Up to now, there are a few reports of making monoclonal antibodies against recombinant hepatitis B core antigen $(\mathrm{HBcAg}$ ) (Hložánek et al. 1987). We established hybridoma clones which produced antibodies specific for HBcAg.

Female Balb/C mice, 8 weeks of age, were injected intraperitonealy at first with $10 \mu \mathrm{g}$ of recombinant $\mathrm{HBcAg}$ in complete Freund's adjuvant, then with the same amount of antigen in incomplete Freund's adjuvant 2 weeks later, and finally with the same amount of $\mathrm{HBcAg}$ alone 4 weeks later. Four days prior to hybridization, mice were injected intravenously with the same dose of the antigen alone. Myeloma NS-1 cells were successfully fused with splenocytes using polyethylene glycol method (Kohler and Milstein 1975). Cells producing anti-HBc were detected by enzyme linked immunosorbent assay (ELISA). Cloning of the cells producing anti-HBc were repeated twice with limiting dilution method. Briefly, 0.2 cells per well were incubated in 96 well culture plates, and 3 clones, $4 \mathrm{C} 8,8 \mathrm{E} 3$ and $8 \mathrm{~F} 9$, were obtained : single colony forming possibilities of these clones at the second cloning were $16 \%, 32 \%$ and $18 \%$, respectively. Isotypes of immunoglobulins produced by these clones are IgA ; K chain, IgM ; K chain and IgM ; K chain, respectively. All supernatants were negative for anti-HBe (data not shown). Every supernatant from each clone contained immunoglobulins bound with recombinant $\mathrm{HBcAg}$ in a dose dependent manner (Fig. 1). In addition, the binding of these antibodies to HBcAg was effectively blocked by addition of rabbit polyclonal anti-HBc (DAKO, Santa Barbara, CA, USA) (Fig. 2). Based on these data, we concluded that the monoclonal antibodies prepared here recognized the antigenic sites of $\mathrm{HBcAg}$.

$\mathrm{HBcAg}$ produces anti-HBc of $\operatorname{IgG}, \operatorname{IgM}$ and $\operatorname{IgA}$ subclasses in patients infected with human hepatitis B virus. Among these subclasses, IgA type anti-HBc may be responsible for liver cell injury (Nomura et al. 1985). But the significance of anti-HBc in terms of hepatic necrosis is still unknown because of limited amount of anti-HBc available from

Received May 9, 1990; revision accepted for publication July 3, 1990.

Abbreviations : anti-HBc, anti-hepatitis B core antibody; anti-HBe, anti-hepatitis B envelope antibody. 


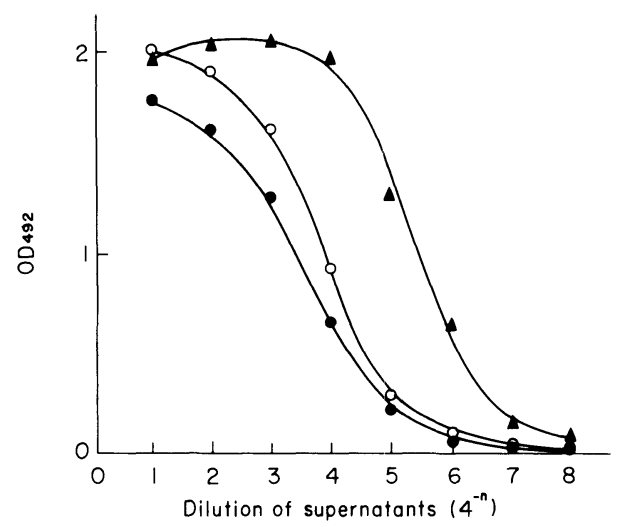

Fig. 1. Binding of monoclonal antibodies to HBcAg. Supernatants of $4 \mathrm{C} 8(\bullet)$, 8E3 $(\Delta)$ and $8 \mathrm{~F} 9(\mathrm{O})$ were diluted in PBS, and added to recombinant $\mathrm{HBcAg}$ coated wells of ELISA plates.

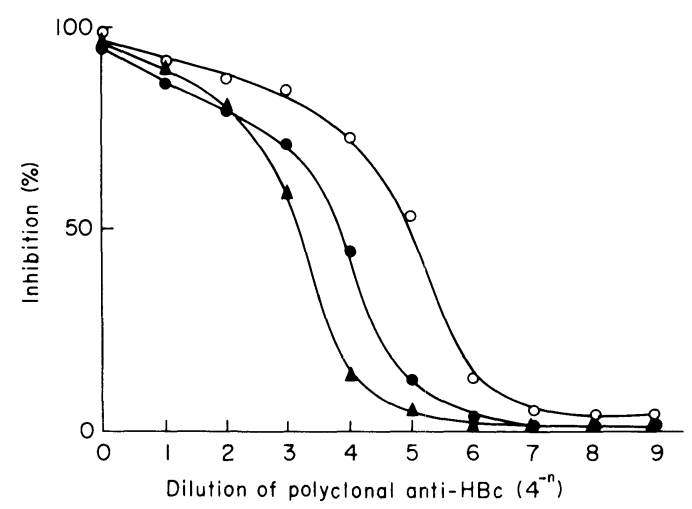

Fig. 2. ELISA for binding specificity of monoclonal antibodies to HBcAg. Prior to the addition of monoclonal antibodies, $\mathrm{HBcAg}$ coated wells were incubated with serially diluted goat polyclonal anti-HBc as an inhibitor. Percent binding inhibitions of monoclonal antibodies, $4 \mathrm{C} 8(\bullet), 8 \mathrm{E} 3(\bullet), 8 \mathrm{~F} 9(\bigcirc)$, were calculated against wells without the inhibitors.

patients' sera. And production of anti-HBc may be regulated by anti-(anti-HBc) idiotype, which will be accurately detected with $\mathrm{HBcAg}$-specific monoclonal antibody. The availability of the monoclonal antibodies described here should make feasible further approaches to these questions.

\section{Acknowledgments}

We thank Dr. Kyosuke Mizuno (Kaketsuken, Kumamoto, Japan) for providing recombinant HBcAg.

\section{References}

1) Hložánek, I., Korec, E., Dostálová, V., Strá, J., König, J., Bichko, V.V., Seichertová, A. \& Gren, E.J. (1987) Monoclonal antibodies against genetically manuplated 
hepatitis B core antigen. Folia Biol. (Praha), 33, 295-300.

2) Kohler, G. \& Milstein, H. (1975) Continuous cluture of fused cells secreting antibody of predefined specificity. Nature, 256, 495-497.

3) Nomura, M., Imai, M., Tsuda, F., Furuta, S., Akahane, Y., Tachibana, K., Usuda, S., Miyakawa, Y. \& Mayumi, M. (1985) Immunoglobulin A antibody against hepatitis $\mathrm{B}$ core antigen in the acute and persistient infection with hapatitis B virus. Gastroenterology, 89, 1109-13. 